\title{
Anogeissus leiocarpus (DC.) Guill and Peer (Combretaceae) and Adansonia digitata L. (Malvaceae), Tropical Medicinal Plants Traditionally Used for the Management of Gastro-intestinal Parasitosis of Small Ruminants: Chemical Composition Study
}

\section{Julienne Kuiseu ${ }^{1,3}$, Pascal Abiodoun Olounlade ${ }^{1 *}$, Geraldo Tchegniho Houmenou $^{1}$, Basile Saka Boni Konmy ${ }^{1}$, Claude Gbemeho Houssoukpe ${ }^{1}$, Tony Taofick Babalola Abiodoun Sounkere ${ }^{1}$, Christian Cocou Dansou ${ }^{1}$, Ibikounle Moudachirou ${ }^{4}$, Severin Babatounde ${ }^{5}$, Sylvie Mawule Houn- zangbe-Adote $^{2}$ and Patrick Aleodjrodo Edorh ${ }^{3}$}

${ }^{1}$ Zootechnics and Livestock Systems Research Unit (URZoSE), Animal and Fisheries

Sciences Laboratory (LaSAH), Doctoral School of Agronomic and Water Sciences

(EDSAE), National University of Agriculture (UNA), Republic of Benin

${ }^{2}$ Laboratory of Ethnopharmacology and Animal Health, Faculty of Agronomic

Sciences, University of Abomey Calavi (UAC), Republic of Benin

${ }^{3}$ Laboratory of Toxicology and Environmental Health (LATSE), University of

Abomey-Calavi (UAC), Republic of Benin

${ }^{4}$ Zoology Laboratory of the Faculty of Science and Technology, University of

Abomey-Calavi (UAC), Cotonou, Republic of Benin

${ }^{5}$ Laboratory of Zootechnics, Faculty of Agronomic Sciences, University of

Abomey-Calavi (UAC), Cotonou, Republic of Benin

*Corresponding Author: Pascal Abiodoun Olounlade, Zootechnics and Livestock

Systems Research Unit (URZoSE), Animal and Fisheries Sciences Laboratory

(LaSAH), Doctoral School of Agronomic and Water Sciences (EDSAE), National

University of Agriculture (UNA), Republic of Benin. Email: abiodouno@yahoo.fr
Received: August 18, 2021

Published: October 18, 2021

(C) All rights are reserved by Pascal Abiodoun Olounlade., et al.

\begin{abstract}
Anogeissus leiocarpus and Adansonia digitata are two tropical medicinal plants with multiple uses in traditional and veterinary medicine. The aim of this study was to characterize phytochemically the leaf powder of both plants used in the treatment of gastrointestinal parasitosis of small ruminants. The phytochemical analysis of leaf powders was based on staining and precipitation reactions. A determination of some chemical constituents of the leaf powder extracts of both plants was carried out. The phytochemical screening revealed the presence of tannins and flavonoids in the two plants that would explain their anthelmintic properties. Nevertheless, the screening of Anogeissus leiocarpus leaf powder revealed the absence of alkaloids. The plant extraction yields were $9.85 \pm 0.64$ and $10.93 \pm 0.66$ respectively for Anogeissus leiocarpus and Adansonia digitata. The dosage of bioactive molecule families showed that total phenols and flavonoids contents were the highest. The total phenols, condensed tannins and flavonoid contents
\end{abstract}

Citation: Julienne Kuiseu., et al. “Anogeissus leiocarpus (DC.) Guill and Peer (Combretaceae) and Adansonia digitata L. (Malvaceae), Tropical Medicinal Plants Traditionally Used for the Management of Gastro-intestinal Parasitosis of Small Ruminants: Chemical Composition Study". Acta Scientific Pharmaceutical Sciences 5.10 (2021): 24-32. 
Anogeissus leiocarpus (DC.) Guill and Peer (Combretaceae) and Adansonia digitata L. (Malvaceae), Tropical Medicinal Plants Traditionally Used for the Management of Gastro-intestinal Parasitosis of Small Ruminants: Chemical Composition Study

were $30.01 \pm 0.09 \mathrm{mg}$ gallic acid equivalent/mg of the dry extract, $9.83 \pm 0.19 \mathrm{mg}$ catechin equivalent/mg of the dry extract and 27.18 $\pm 0.45 \mathrm{mg}$ rutin equivalent/mg of the dry extract of Anogeissus leiocarpus, respectively. The leaf powder extract of Adansonia digitata also contained significant amounts of total phenols (25.87 $\pm 0.12 \mathrm{mg}$ gallic acid equivalent/mg of the dry extract), condensed tannins (17.32 $\pm 0.13 \mathrm{mg}$ catechin equivalent/mg of the dry extract) and flavonoids (21.37 $\pm 0.09 \mathrm{mg}$ rutin equivalent/mg of the dry extract). These chemical characteristics are conducive to the rational and industrial use of the two target plant species in the management of gastrointestinal parasitosis and other diseases of small ruminants.

Keywords: Anogeissus leiocarpus; Adansonia digitata; Total Phenols; Tannins; Flavonoids; Bioactive Molecules; Natural Anthelmintics; Gastro-intestinal Parasitosis; Small Ruminants

\section{Abbreviations}

GAE: Gallic Acid Equivalent; CE: Catechin Equivalent; RE: Rutin Equivalent; DE: Dry Extract; LNP: National Laboratory of Pharmacognosy; URZoSE: Zootechnics and Livestock System Research Unit; LaSAH: Animal and Fisheries Sciences Laboratory; UNA: National University of Agriculture; $\mathrm{AlCl}_{3}$ : Aluminum Trichloride; $\mathrm{Na}_{2} \mathrm{CO}_{3}$ : Sodium Carbonate; HNB: National Herbarium of Benin; ANOVA: Analysis of Variance.

\section{Introduction}

African flora is rich in species such as Adansonia digitata and Anogeissus leiocarpus found in several countries [1,2]. The Adansonia digitata species is native to Africa and widely spread in savannahs and forests in sub-Saharan regions. The species is found in Malawi, Zimbabwe, Mozambique, Mali, Benin, Senegal, Côte d'Ivoire, Cameroon, Burkina Faso, Kenya, Uganda, Tanzania, and in South Africa specially in the warm regions of Limpopo province [2]. The A. leiocarpus species is usually found in Cameroon, Ethiopia and West Africa. It grows in dry forests and forest galleries [1].

Adansonia digitata is a large tree which can reach 18 to $25 \mathrm{~m}$ in height. Its diameter can reach $5 \mathrm{~m}$ to $20 \mathrm{~m}$ [3]. Its leaves are large and are divided between five and seven conical foliates on a single, and thin petiole [3]. The A. digitata bark is smooth, grey with blue or purpurine reflections $[2,4]$. Anogeissus leiocarpus is a tree with 15 to $18 \mathrm{~m}$ in height and a trunk that can measure $1 \mathrm{~m}$ in diameter. Its bark is grayish to beige in color and bears thin scales. The leaves of $A$. leiocarpus are acute at the apex, attenuated at the base and pubescent below [1].
Adansonia digitata is endowed with several therapeutic properties. The methanolic extract of A. digitata leaf powder has antidiabetic and hypolipidemic properties and improves hematological parameters [5]. In terms of food, the fruit of this tree is consumed by the African population. Pulps are powerful sources of vitamin and mineral [6]. The seeds are sufficiently rich in protein and fatty elements. They have an industrial interest, especially in cosmetics [7]. Similarly, Anogeissus leiocarpus is used in African tradition for therapeutic purposes to control microbial and helminthic diseases [8]. Indeed, the bark of the tree trunk is used against anorexia, constipation, malaria, jaundice, asthma, cough and bronchitis. The bark is also used as an antihypertensive, aphrodisiac, dewormer, antiseptic, astringent and healing. Its leaves can be used to treat jaundice, brain colds, asthma, cough and bronchitis. They are also used against helminthiasis, diarrhoea and leprosy [9]. However, leafy twigs are effective against migraine or amoebic dysentery. The stem bark of $A$. leiocarpus contains phytochemicals ingredients that could be processed into antimicrobial drugs, useful for the treatment of diseases caused by some microorganisms [10].

The chemical ingredients present in these plants could be responsible for the therapeutic effects [11]. Previous studies on $A$. digitata have focused on the pulp of its fruits [12]. They focused less on the chemical composition [13] of species leaves.

About A. leiocarpus, the few phytochemical studies reviewed focused on phytochemical screening of roots [14] and on ethanolic extract of the leaves [15]. Among all the documents consulted, only [16] addressed the determination of chemical compounds of A. leiocarpus leaves (ethanolic extract) of about 10 years.

Citation: Julienne Kuiseu., et al. “Anogeissus leiocarpus (DC.) Guill and Peer (Combretaceae) and Adansonia digitata L. (Malvaceae), Tropical Medicinal Plants Traditionally Used for the Management of Gastro-intestinal Parasitosis of Small Ruminants: Chemical Composition Study". Acta Scientific Pharmaceutical Sciences 5.10 (2021): 24-32. 
Anogeissus leiocarpus (DC.) Guill and Peer (Combretaceae) and Adansonia digitata L. (Malvaceae), Tropical Medicinal Plants Traditionally Used for the Management of Gastro-intestinal Parasitosis of Small Ruminants: Chemical Composition Study

The present study was focused on the chemical composition determination of two plants through phytochemical screening and the dosage of some compounds of leaves powders for their subsequent use in the management of gastrointestinal nematodes of small ruminants.

\section{Material and Methods Material}

The plant material consisted of Adansonia digitata and Anogeissus leiocarpus leaves harvested in the rainy season in the Commune of Kétou located in the Plateau department of South Benin. These leaves were certified at the National Herbarium of the University of Abomey-Calavi under the identification numbers: YH 481/HNB for A. leiocarpus and YH 482/HNB for A. digitata. They were dried for 14 days at room temperature, in the shade, away from the sun to preserve sensitive phytochemicals. The dry leaves were crushed using an electric mill (of Flour MILLS NIGERIA EI MOTOR No 1827) with a sieve of 710 micrometers mesh. The powders obtained were stored in airtight sealed. Figure 1 shows the tree (a) and leaves (b) of $A$. digitata, the leafy stems of A. leiocarpus (c) and the preserwed powders.

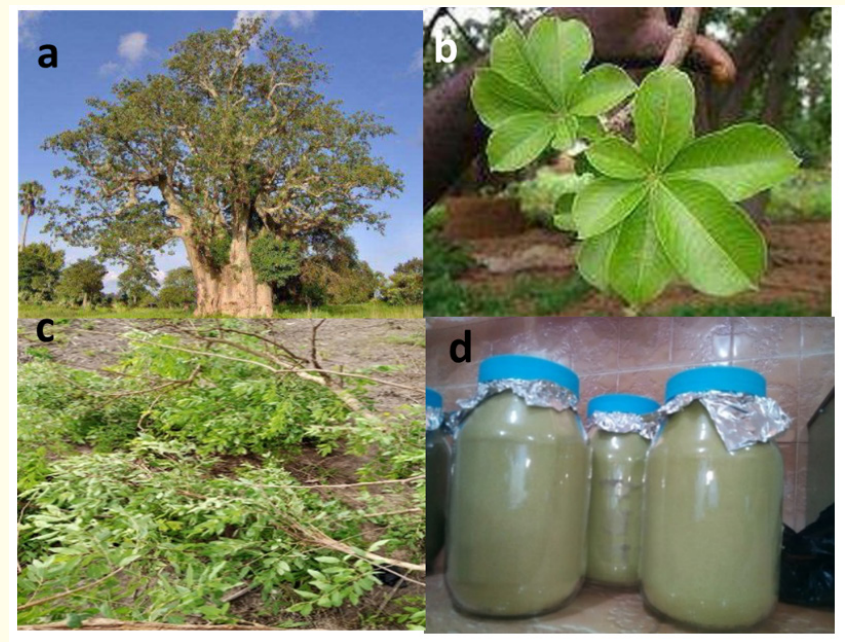

Figure 1: a: Adansonia digitata tree; b: A. digitata leaves; c: leafy stems of Anogeissus leiocarpus; d: preserved leaf powders.
Methods

\section{Phytochemical screening}

Different qualitative tests were conducted on leaf powder of each of the plants to identify the main groups of active chemical compounds contained in these plants. The tube test procedures are based on staining and precipitation reactions according to the classical method of Houghton and Raman [17].

\section{Preparation of crude extracts of the two plants}

The ethanolic extracts were prepared by dissolving $100 \mathrm{~g}$ of leaf powder of each plant in $1000 \mathrm{~mL}$ of ethanol at $60^{\circ}$. The mixtures were stir-in continuously for 72 hours. The macerates were filtered 3 times with hydrophilic cotton and then on Watman $\mathrm{N}^{\circ} 1$ paper. Each filtrate was transferred to a $1000 \mathrm{~mL}$ flask and then evaporated at $57^{\circ} \mathrm{C}$ by using a rotavapor (Heidolph Laborota 4000 efficient) coupled to a water cooler (Julabo FL 300). The concentrated extracts were dried in the oven $\left(40{ }^{\circ} \mathrm{C}\right)$ and then weighed to determine the extraction yields.

\section{Determination of some large groups of bioactive families} Determination of total phenols

The method described by [18] was used to determine the total phenol content. From a methanolic stock solution of gallic acid, with a mass concentration of $10 \mathrm{mg} / \mathrm{mL}$, a standard range of standard solutions by successive dilutions was prepared.

An amount of $125 \mu \mathrm{L}$ of standard solutions was put into a test tube and then $625 \mu \mathrm{L}$ of the $10 \%$ Folin-Ciocalteu reagent was added. After 5 minutes of incubation, $500 \mu \mathrm{L}$ of sodium carbonate $\left(\mathrm{Na}_{2} \mathrm{CO}_{3}\right)$ at $75 \mathrm{mg} / \mathrm{mL}$ were added to the mixture. The tubes were then stirred and incubated for 2 hours at room temperature.

The absorbance of each solution was measured using a UV-Visible spectrophotometer reader at a wavelength of $760 \mathrm{~nm}$ against a blank prepared under the same conditions.

\section{Determination of flavonoids}

Flavonoids were quantified according to the method $[19,20]$ using aluminium trichloride ( $\mathrm{AlCl} 3$ ) as a reagent. A stock solution of rutin with a mass concentration of $10 \mathrm{mg} / \mathrm{mL}$ was prepared in methanol. From this stock solution, a standard range of standard

Citation: Julienne Kuiseu., et al. “Anogeissus leiocarpus (DC.) Guill and Peer (Combretaceae) and Adansonia digitata L. (Malvaceae), Tropical Medicinal Plants Traditionally Used for the Management of Gastro-intestinal Parasitosis of Small Ruminants: Chemical Composition Study". Acta Scientific Pharmaceutical Sciences 5.10 (2021): 24-32. 
Anogeissus leiocarpus (DC.) Guill and Peer (Combretaceae) and Adansonia digitata L. (Malvaceae), Tropical Medicinal Plants Traditionally Used for the Management of Gastro-intestinal Parasitosis of Small Ruminants: Chemical Composition Study

solutions were equally prepared. A volume of $500 \mu \mathrm{L}$ of each standard solution was placed in a test tube followed by the addition of $500 \mu \mathrm{L}$ of $2 \%$ aluminium trichloride and $3 \mathrm{~mL}$ of methanol. The tubes were then stirred slightly and incubated in the dark for 10 minutes at room temperature. The absorbance of each solution was measured using the spectrophotometer reader at a wavelength of $415 \mathrm{~nm}$ against a blank consisting of $500 \mu \mathrm{L}$ of AlCl3 and $3.5 \mathrm{~mL}$ of methanol.

\section{Determination of condensed tannins}

The determination of condensed tannins in plant extracts was carried out according to the [21] method. For $500 \mu \mathrm{L}$ of the standard solution, $3 \mathrm{~mL}$ of vanillin solution (4\%) prepared in methanol were added. Added to this $1.5 \mathrm{~mL}$ of steaming concentrated hydrochloric acid and $2 \mathrm{~mL}$ of methanol.

The mixture was incubated during $15 \mathrm{~min}$ and the absorbance was measured at $500 \mathrm{~nm}$ by spectrophotometer reader. Condensed tannin concentrations were derived from the calibration ranges established with catechin $(5 \mathrm{mg} / \mathrm{mL})$ and expressed in milligram catechin equivalent per milligram of extract.

\section{Statistical analyses}

The data was recorded in Excel spreadsheet of Microsoft Office 2016. This Office was also used to construct equation lines based on optical densities and mass concentrations of extracts.

The equations of the determined compounds permitted to determine the condensed tannin, alkaloid and flavonoid contents of both plants' extracts. The means plus or minus standard deviation values of the grades and the extraction yields were calculated using the R Software version 4. 0. 2. This software was also used to perform the analysis of variance (ANOVA) at the threshold of $5 \%$ of yields and phytochemical contents.

\section{Results}

\section{Phytochemical composition}

The phytochemical analysis results of the leaf powders of Anogeissus leiocarpus and Adansonia digitata are recorded in table 1. This Table shows that both plants contain tannins, reducing compounds, flavonoids and anthocyanins with a high abundance of catechic tannins and Leuco-anthocyanins. However, they are all lacking quinonic and cyanogenic compounds, Triterpenoids, and cardiotonic glycosides. Only A. leiocarpus contains steroids with an abundant presence of saponosides, but it has no alkaloids and anthracenics.

\begin{tabular}{|l|c|c|}
\hline Compounds & A. leiocarpus & A. digitata \\
\hline Catechical tannins & +++ & ++ \\
\hline Gallic tannins & +++ & + \\
\hline Flavonoids & ++ & + \\
\hline Leuco-anthocyanins & +++ & +++ \\
\hline Saponosides & +++ & - \\
\hline Mucilages & - & ++ \\
\hline Quinonic derivatives & - & - \\
\hline Cyanogenic derivatives & - & - \\
\hline Coumarins & ++ & + \\
\hline Alkaloids & - & ++ \\
\hline Anthocyanins & + & ++ \\
\hline Triterpenoids & - & - \\
\hline Steroids & + & - \\
\hline Free anthracenics & +++ & + \\
\hline Combined anthracenics & - & ++ \\
\hline O-heterosides & + & ++ \\
\hline C-heterosides & + & ++ \\
\hline Cardiotonic glycosides & + & + \\
\hline Reducing compounds & + & + \\
\hline
\end{tabular}

Table 1: Results of phytochemical screening of Anogeissus leiocarpus and Adansonia digitata leaf powders.

$(+)$ : Presence; (++): Abundance; (+++): High Abundance; (-): Absence.

\section{Extraction yields of both plants}

Table 2 below presents the extraction yields of the plants studied calculated using the following formula:

$$
\text { Yield }(\%)=\frac{\text { Dry extract mass }(g)}{\text { Initial mass of powder }(g)} \times 100
$$

The analysis of variance revealed a non-significant difference at the $5 \%$ threshold between the extraction yields of the two plants. 
Anogeissus leiocarpus (DC.) Guill and Peer (Combretaceae) and Adansonia digitata L. (Malvaceae), Tropical Medicinal Plants Traditionally Used for the Management of Gastro-intestinal Parasitosis of Small Ruminants: Chemical Composition Study

\begin{tabular}{|l|c|c|}
\hline Plant species & Extraction yield (\%) & P value \\
\cline { 1 - 2 } A. digitata & $10.93 \pm 0.66$ & \multirow{2}{*}{0.096} \\
\cline { 1 - 2 } A. leiocarpus & $9.85 \pm 0.64$ & 0.096 \\
\hline
\end{tabular}

Table 2: Extraction yields.

Contents of total phenols, flavonoids and condensed tannins

The results of the determination of phenolic compounds, flavonoids and condensed tannins are presented in table 3. The different contents were determined from the equation lines of each calibration curve (Figures 2, 3 and 4).

\begin{tabular}{|l|c|c|c|}
\hline Plant species & A. leiocarpus & A. digitata & p-value \\
\hline Chemical groups & \multicolumn{3}{|c|}{ Content } \\
\hline $\begin{array}{l}\text { Total phenol (mg } \\
\text { GAE/mg DE) }\end{array}$ & $30.01 \pm 0.09^{\mathrm{a}}$ & $25.87 \pm 0.12^{\mathrm{b}}$ & 0.0021 \\
\hline $\begin{array}{l}\text { Condensed tannins } \\
\text { (mg EC/mg DE) }\end{array}$ & $9.83 \pm 0.19^{\mathrm{a}}$ & $17.32 \pm 0.13^{\mathrm{b}}$ & 0.0001 \\
\hline $\begin{array}{l}\text { Flavonoids (mg RE/ } \\
\text { mg DE) }\end{array}$ & $27.18 \pm 0.45^{\mathrm{a}}$ & $21.37 \pm 0.09^{\mathrm{b}}$ & 0.0001 \\
\hline
\end{tabular}

Table 3: Results of some bioactive family large groups determination.

GAE: Gallic Acid Equivalent; CE: Catechin Equivalent; RE: Rutin Equivalent; DE: Dry Extract.

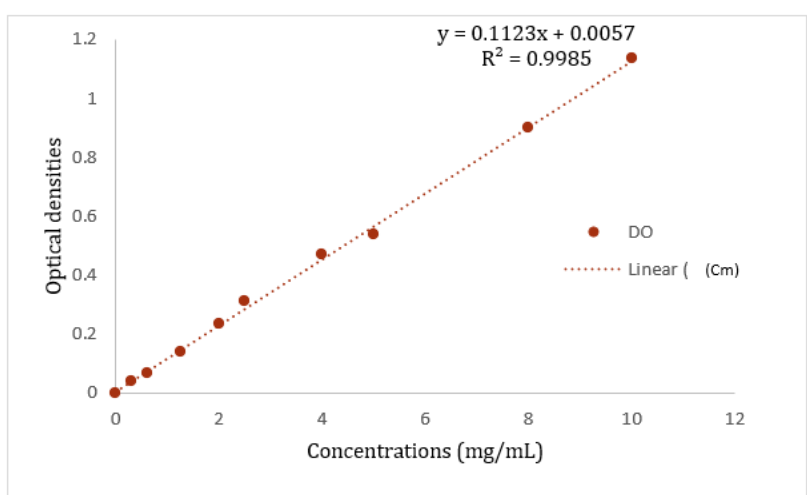

Figure 2: Gallic acid calibration curve for the total phenols' determination.

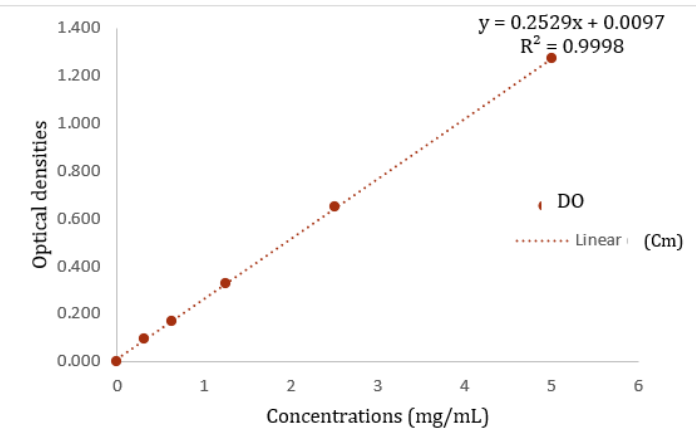

Figure 3: Catechin calibration curve for the condensed tannin determination

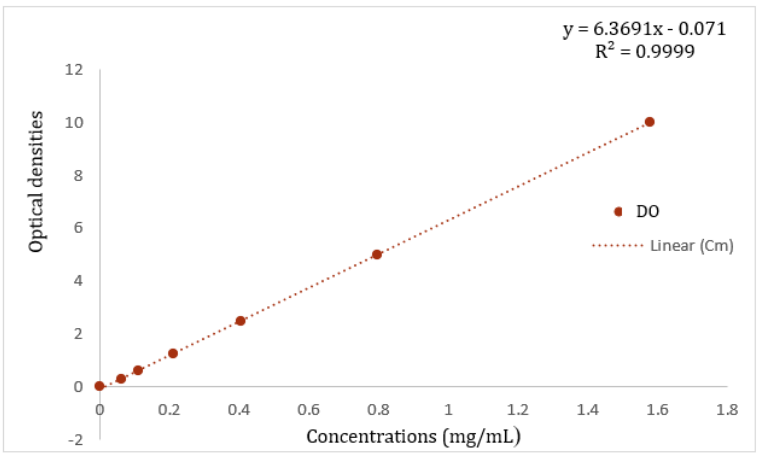

Figure 4: Rutin calibration curve for flavonoid determination.

The different letters $\mathrm{a}$ and $\mathrm{b}$ on the same line have different means $(\mathrm{p}<0.05)$.

Table 3 shows that the chemical compound contents vary within plants but also differ from one plant to another. It is noted that the condensed tannin content of $A$. digitata $(17.32 \pm 0.13 \mathrm{mg} \mathrm{CE} / \mathrm{mg}$ $\mathrm{DE}$ ) is almost the double of that of A. leiocarpus ( $9.83 \pm 0.19 \mathrm{mg} \mathrm{CE}$ / $\mathrm{mg}$ DE). However, the flavonoid content of A. leiocarpus (27.18 \pm $0.45 \mathrm{mg} \mathrm{RE} / \mathrm{mg} \mathrm{DE}$ ) is higher than that of $A$. digitata extracts (21.37 $\pm 0.09 \mathrm{mg} \mathrm{RE} / \mathrm{mg} \mathrm{DE}$ ). A similar trend can be observed for the total 
Anogeissus leiocarpus (DC.) Guill and Peer (Combretaceae) and Adansonia digitata L. (Malvaceae), Tropical Medicinal Plants Traditionally Used for the Management of Gastro-intestinal Parasitosis of Small Ruminants: Chemical Composition Study

phenols of $A$. leiocarpus. The analysis of variance showed that these differences are significant at the $5 \%$ threshold.

\section{Discussion}

\section{Phytochemical screening}

The phytochemical studies led to the identification of several families of chemical compounds in the two plant leaves. Several chemical constituents of plants were precursors of the pharmacological effects [22]. Overall, the phytochemicals found varied from plant to plant with a complete absence of cyanogenic derivatives in both plants. This could be explained by the nature and the characteristics of each species. The phytochemical screening permitted to identify tannins, flavonoids, leuko-anthocyanins, saponosides, coumarins, anthocyanins, heterosides ( $\mathrm{O}$ and $\mathrm{C}$ ), reducing compounds and free anthracenics in A. leiocarpus leaf powder. Only eight groups of chemical compounds were identified in the bark powder of the same species including tannins, flavonoids, alkaloids, terpenes and saponosides [22]. The type of organs used could explain these results [15], however, did not find the coumarins, free anthracenics and glycosides in ethanolic extracts of A. leiocarpus leaves but contrary to this study, they found quinonic derivatives in those extracts. The results of the present study were similar to those of [14] in Nigeria, but they revealed the presence of alkaloids and terpenes in the root powder of A. leiocarpus except tannins, flavonoids and saponosides.

The phytochemical characterization of Adansonia digitata leaves' powder revealed the presence of several chemical compounds including: tannins, flavonoids, leuko-anthocyanins, coumarins, alkaloids, mucilages, anthocyanins, free anthracenics, combined anthracenics, glycosides ( $\mathrm{O}$ and $\mathrm{C})$ and reducing compounds. [12] were interested in the study of $A$. digitata root tubers at the University of Mzuzu in Zambia. The phytochemical analysis of these tubers revealed the absence of both alkaloids and flavonoids, but shown the presence of terpenoids and saponins in the five dry crushed samples used. This present study found similar results to those of [23] who noted in addition to steroids, the presence of tannins, saponins, triterpenoids and alkaloids in the leaf powder extracts of $A$. digitata leaves. There was also a clear difference in the results from hexanic, benzene, chloroform and methanolic extracts [23]. This argues that the solvents used could influence the reveal reactions of the chemical compounds. The different results observed on both sides would come not only from the plant organs used but also from the methods used to perform the phytochemical analyses [15]. Also, these differences can be explained by the vegetative stage of the plant, the time of harvest and the environment and pedoclimatic conditions [11,24].

\section{Plant extraction yields}

The extraction yield of the A. leiocarpus leaf powder differed from that of the $A$. digitata leaf powder. The yield of the extract $(10.93 \pm 0.66)$ of the leaf powder of $A$. digitata was higher than that of the hydroethanolic extract of fruit powder of the same species (9.37\%) found by Li and others [13]. With pulp powder of $A$. digitata fruits collected in four different localities, [25] obtained yields ranging from $55.50 \%$ to $66.70 \%$ and $32.49 \%$ to $37.94 \%$ respectively from aqueous and ethanolic extractions (70\% ethanol). These yields were all higher than those found in this study.

The extraction powder of $A$. leiocarpus leaves gave the yield of $9.85 \pm 0.64$ which was about seven times that of $1.5 \%$ found by [26] after an aqueous extraction of the stems. These differences in yields would be due to several factors including the species and the organ of the plant, and the extraction solvent used.

Determination of total phenols, flavonoids and condensed tannins

The total phenols, flavonoids and tannins condensed in the ethanolic extracts of $A$. digitata and $A$. leiocarpus was determined using gallic acid, rutin and catechin respectively as standards. The presence of these large groups of secondary metabolites in both plants was confirmed. Indeed, the total phenols followed by flavonoids have the highest levels of bioactive compounds. These results corroborate those of the phytochemical screening that found tannins and flavonoids in the two species leaf powders. The polyphenol content (3.858 $\mathrm{mg} \mathrm{GAE} / \mathrm{g}$ of the dry extract) of roasted seed cakes of Adansonia digitata evaluated by [27] in Senegal was much lower than those found in this study $(25.87 \pm 0.12 \mathrm{mg} \mathrm{GAE} / \mathrm{mg}$ dry extract) of Adansonia digitata leaf extracts. Elsewhere, in Côte d'Ivoire, a total phenol content estimated at $6.8310 \mathrm{mg} \mathrm{GAE} / \mathrm{g}$ of the dry extract was found in A. digitata pulp extracted with a mixture of ethanol and water [28]. This difference could be explained by differences in organs and extraction solvents. 
Anogeissus leiocarpus (DC.) Guill and Peer (Combretaceae) and Adansonia digitata L. (Malvaceae), Tropical Medicinal Plants Traditionally Used for the Management of Gastro-intestinal Parasitosis of Small Ruminants: Chemical Composition Study

According to [29], difference between regions can also explain changes noted the contents. These authors found total phenol and flavonoid contents resulting from different regions varied from 10.67 to $39.27 \mathrm{mg} \mathrm{GAE} / \mathrm{g}$ of the dry extract and 7.74 to $24.82 \mathrm{mg}$ GAE/g of the dry extract, respectively. These values was lower than those found in this study with the ethanolic extracts of Adansonia digitata leaf powder. [16] in Ghana found total phenols (1294.81 $\pm 3 \mathrm{mg} \mathrm{EAG} / \mathrm{g}$ dry extract) and flavonoids (330.72 $\pm 29 \mathrm{mg}$ EC/g dry extract) in the methanolic extract of $A$. leiocarpus leaves which were different from those of this study.

The pedoclimatic conditions, harvest seasons, plant genetic characteristics, drying method and the development stage of the leaves during the harvest time could explain the various contents of these bioactive compounds found in the plants according to [30,31]. Phenols, flavonoids and tannins are precursor molecules of antiparasitic effects [24,32]. Indeed, the presence of tannins in some plant species would be at the origin of their anthelmintic effects [24]. Similarly, the significant presence of flavonoids in the extracts of both plants predisposes them to an efficient control of gastrointestinal parasites [33]. A high tannin content would increase the effectiveness of plants in inhibiting the gastrointestinal nematode development stages in small ruminants [34]. They, they were at the origin of the larval inhibition caused by medicinal plants used by breeders to treat parasitic diseases in sheep and goat farms [35]. Furthermore, it was noted that the two plants studied could be used to reduce oxidative stress and produce antibacterial effects $[15,16]$. [36,37] reported that the anti-oxidative and antibacterial effects are related to phenolic compounds including flavonoids [38,39]. [14] report that the analgesic, stimulant and anti-cancer therapeutic effects revealed by A. leiocarpus bark trunk are related to alkaloids, saponines and flavonoids. However, [15] argue that the antibacterial property of plants comes from a combination of the beneficial effects of tannins and alkaloids.

\section{Conclusion}

The phytochemical screening and the determination of ethanolic extracts of $A$. leiocarpus and $A$. digitata leaf powders used in African veterinary pharmacopoeia for the management of gastrointestinal parasites of small ruminants revealed that they are both rich in chemical elements precursors of therapeutic effects.
The determination of some large groups of chemical compounds showed significant levels of tannins, flavonoids and alkaloids in the leaf extracts of $A$. leiocarpus and $A$. digitata. The presence of these chemical compounds encourages a rational use of both tropical medicinal plants to control gastrointestinal parasitosis and other pathologies in small ruminants.

In perspective, it would be useful to carry out high-performance and bio-guided chromatographic analyses to isolate the bioactive molecules of the two plants studied and to have more capital elements for their development and valorization.

\section{Acknowledgement}

The authors express their gratitude to the staff of the National Laboratory of Pharmacognosy of Porto-Novo (LNP), Benin. They also thank the members of the research team of the Zootechnics and Livestock System Research Unit (URZoSE) of the Animal and Fisheries Sciences Laboratory (LaSAH) of the National University of Agriculture (UNA), Benin.

\section{Bibliography}

1. Arbab AH. "Review on Anogeissus leiocarpus a potent African traditional drug". International Journal of Research in Pharmacy and Chemistry 4.3 (2014): 496-500.

2. Kamatou G., et al. "An updated reviw of Adansonia digitata: A commercially important African tree". South African Journal of Botany 77.4 (2011): 908-919.

3. Van Wyk A and Prinsloo G. "A review of the ethnobotanical uses, pharmacology, toxicology, management and cultivation of selected South African protected multi-purpose tree species". South African Journal of Botany 124 (2019): 258-269.

4. Chadare F., et al. "Baobab food products: a review on their composition and nutritional value". Critical Reviews in Food Science and Nutrition 49.3 (2008): 254-274.

5. Ebaid H., et al. "Efficacy of a methanolic extract of Adansonia digitata leaf in alleviating hyperglycemia, hyperlipidemia, and oxidative stress of diabetic rats". BioMed Research International 2019 (2019): 1-10. 
Anogeissus leiocarpus (DC.) Guill and Peer (Combretaceae) and Adansonia digitata L. (Malvaceae), Tropical Medicinal Plants Traditionally Used for the Management of Gastro-intestinal Parasitosis of Small Ruminants: Chemical Composition Study

6. Stadlmayr B., et al. "Nutrient composition of selected indigenous fruits from sub-Saharan Africa". Journal of the Science of Food Agriculture 93.11 (2013): 2627-2636.

7. Gebauer J., et al. "Baobab (Adansonia digitata L.): a review on a multipurpose tree with promising future in the Sudan". Gartenbauwissenschaft 67.4 (2002): 155-160.

8. Agaie B and Onyeyili P. "Anthelmintic activity of the crude aqueous leaf extracts of Anogeissus leiocarpus in sheep". African Journal of Biotechnology 6.13 (2007): 1511-1515.

9. Sereme A., et al. «Propriétés thérapeutiques des plantes à tanins du Burkina Faso». Pharmacopée et Médecine Traditionnelle Africaine 15 (2008): 41-49.

10. Usman A., et al. «Phytochemical and antimicrobial studies of stem-bark extracts of Anogeissus leiocarpus found in dutsin-Ma, Katsina-Nigéria». Fudma Journal of Sciences 4.2 (2020): 156-167.

11. Koukoui O., et al. "Phytochemical study and evaluation of cytotoxicity, antioxidant and hypolipidemic properties of Launaea taraxacifolia leaves extracts on cell lines HepG2 and PLB985". American Journal of Plant Sciences 6.11 (2015): 1-11.

12. Kamanula M., et al. "Mineral and phytochemical composition of baobab (Adansonia digitata L.) root tubers from selected natural populations of Malawi”. Malawi Medical Journal 30.4 (2018): 250-255.

13. Li X-N., et al. "Profiling hydroxycinnamic acid glycosides, iridoid glycosides, and phenylethanoid glycosides in baobab fruit pulp (Adansonia digitata)". Food Research International (Ottawa, Ont.) 99 (2017): 755-761.

14. Salau A., et al. "Cytotoxic activity of aqueous extracts of Anogeissus leiocarpus and Terminalia avicennioides root barks against Ehrlich ascites carcinoma cells". Indian journal of pharmacology 45.4 (2013): 381-386.

15. Ganfon H., et al. «Activité antibactérienne de l'extrait éthanolique et des fractions de Anogeissus leiocarpa (DC) Guill. Et Perr. (Combretaceae)". International Journal of Biological Chemical Sciences 13.2 (2019): 643-651.
16. Barku V., et al. "In vitro assessment of antioxidant and antimicrobial activities of methanol extracts of six wound healing medicinal plants". Journal of Natural Sciences Research 3.1 (2013): 74-80.

17. Houghton $P$ and Raman A. "A Laboratory handbook for the fractionation of natural extracts". Chapman et Hall, London. New York (1998): 1-199.

18. Singleton V., et al. "Analysis of total phenols and other oxidation substrates and antioxidants by means of folin-ciocalteu reagent”. Methods in Enzymology 299 (1999): 152-178.

19. Kim D-k., et al. "Quantification of polyphenolics and their antioxidant capacity in fresh plums". Journal of Agricultural Food Chemistry 51.22 (2003): 6509-6515.

20. Zhishen J., et al. "The determination of flavonoid contents in mulberry and their scavenging effects on superoxide radicals". Food Chemistry 64.4 (1999): 555-559.

21. Heimler D., et al. "Antiradical activity and polyphenol composition of local Brassicaceae edible varieties". Food Chemistry 99.3 (2006): 464-469.

22. Sanogo Y., et al. «Evaluation in vitro de l'activité des écorces de tige de Anogeissus leiocarpus (DC) Guill. et Perr. (Combretaceae) sur des bactéries responsables de maladies courantes en Afrique et criblage phytochimique». International Journal of Biological Chemical Sciences 10.3 (2016): 1139-1152.

23. Krishnappa K., et al. "Larvicidal and repellent properties of Adansonia digitata against medically important human malarial vector mosquito Anopheles stephensi (Diptera: Culicidae)". Journal of Vector Borne Diseases 49 (2012): 86-90.

24. Dedehou VFGN., et al. «Effets in vitro des feuilles de Pterocarpus erinaceus et des cosses de fruits de Parkia biglobosa sur deux stades du cycle de développement de Haemonchus contortus nématode parasite gastro-intestinal de petits ruminants «. Journal of Animal and Plant Sciences 22.1 (2014): 3368-3378.

25. Coulibaly E. «Contrôle de qualité et formulation galénique (granulés, comprimés) de la poudre de pulpe du fruit de Adan-

Citation: Julienne Kuiseu., et al. "Anogeissus leiocarpus (DC.) Guill and Peer (Combretaceae) and Adansonia digitata L. (Malvaceae), Tropical Medicinal Plants Traditionally Used for the Management of Gastro-intestinal Parasitosis of Small Ruminants: Chemical Composition Study". Acta Scientific Pharmaceutical Sciences 5.10 (2021): 24-32. 
sonia digitata L. (Bombacaceae)». Université de Bamako, Sénégal (2009): 1-136.

26. Diatta B., et al. «Activités antimicrobiennes des plantes utilisées comme bâtonnets frotte-dents (cure-dents) par les Peul de la commune de Tessékéré (Ferlo Nord, Sénégal)». International Journal of Biological Chemical Sciences 13.3 (2019): 1444-1457.

27. Sow A., et al. «Optimisation de la torréfaction des tourteaux de graines de baobab (Adansonia digitata L.) par la méthode des surfaces de réponses». Journal de la Société Ouest-Africaine de Chimie 45 (2018): 42-48.

28. Pamba K., et al. «Caracterisation biochimique et microbiologique de la pulpe de baobab (Adansonia digitata) vendue sur le marche d'Abidjan». American Journal of Innovative Research and Applied Sciences (2018): 320-340.

29. Ali 0., et al. «Composition phytochimique, nutritionnelle et activité antioxydante des feuilles de baobab de Côte d'Ivoire». Journal of Applied Biosciences 141.1 (2019): 14391-14399.

30. Sreelatha S and Padma P. "Antioxidant activity and total phenolic content of Moringa oleifera leaves in two stages of maturity". Plant Foods for Human Nutrition 64 (2009): 303-311.

31. Zhang M., et al. "Phytochemicals, antioxidant and antimicrobial activity of Hibiscus sabdariffa, Centella asiatica, Moringa oleifera and Murraya koenigii leaves". Journal of Medicinal Plants Research 5 (2011): 6672-6680.

32. Olounladé A., et al. "Effet in vivo de Newbouldia laevis (Bignoniaceae) sur des strongles gastro-intestinaux des moutons". European Scientific Journal 13 (2017): 335-351.

33. Brunet S., et al. "Effects of sainfoin (Onobrychis viciifolia) extract and monomers of condensed tannins on the association of abomasal nematode larvae with fundic explants". International Journal for Parasitology 38 (2008): 783-790.

34. Hoste H., et al. "Identification and validation of bioactive plants for the control of gastrointestinal nematodes in small ruminants". Options Méditerranéennes A.85 (2009): 431-436.
35. Olounladé AP., et al. «Etude in vitro de l'effet des tanins de Newbouldia laevis et de Zanthoxylum zanthoxyloïdes sur la migration des larves infestantes de Haemonchus contortus». International Journal of Biological Chemical Sciences 5.4 (2011): 1414-1422.

36. Irondi E., et al. "Blanching influences thephenolics composition, antioxidant activity, and inhibitory effect of Adansonia digitata leaves extract on $\alpha$-amylase, $\alpha$-glucosidase, and aldose reductase". Food Science and Nutrition 5 (2017): 233-242.

37. Sokeng A., et al. "Metabolite characterization of powdered fruits and leaves from Adansonia digitata L. (Baobab) : A multi-methodological approach". Food Chemistry 272 (2019): 93-108.

38. Upadhyay R. "Plant natural products : Their pharmaceutical potential against disease and drug resistant microbial pathogens". Journal of Pharmacy Research 4 (2011): 1179-1185.

39. Nafiu M., et al. "Phytochemical and mineral constituents of Cochlospermum planchonii (Hook. Ef. x Planch) root". Biores Bulletin 5 (2011): 51-58.

Volume 5 Issue 10 October 2021

(C) All rights are reserved by Pascal Abiodoun

Olounlade., et al. 